\title{
Entrepreneurship: First Results from Russia
}

\author{
Simeon Djankov* \\ Edward Miguel \\ Yingyi Qian \\ Gérard Roland \\ Ekaterina Zhuravskaya
}

August 2004

\begin{abstract}
We study the determinants of the decision to become an entrepreneur in 7 Russian cities. Using data on 400 entrepreneurs and 440 non-entrepreneurs, we find considerable variation in the proportion of entrepreneurs, ranging from $6 \%$ of adult population in Nizhny Novgorod, to $16 \%$ in Perm and $18 \%$ in Taganrog. We find evidence that social network effects play a large role in determining entrepreneurial behavior: those individuals whose relatives and childhood friends are entrepreneurs are more likely to be entrepreneurs. Individual characteristics including academic success and educational background, performance on a test of cognitive ability, personal confidence, greed, and willingness to take risks are also important determinants of entrepreneurship in Russia, echoing the claims of Schumpeter. Certain aspects of the institutional environment play a role, but are secondary to individual characteristics.
\end{abstract}

\footnotetext{
${ }^{*}$ The authors are at the World Bank, UC Berkeley and NBER, UC Berkeley, UC Berkeley and CEPR, CEFIR and CEPR, respectively. We thank Irina Levina for excellent research assistance, and the International Finance Corporation for financial support.
} 


\section{Introduction.}

It has been increasingly recognized that entrepreneurship plays a crucial role in successful economies. The Schumpeterian approach to growth (Aghion and Howitt, 1997) advances the view that entrepreneurial dynamism is the key to innovation and growth. A growing body of research also emphasizes the role of entrepreneurs and the development of a vibrant small and medium enterprise sector in the process of economic development (World Bank, 2003). Understanding the factors that enable and hinder entrepreneurial activities is thus at the heart of this research agenda.

Paradoxically, entrepreneurship is an underresearched topic in the social sciences - and especially in economics. It was not always so. Schumpeter (1934) discusses the role of the entrepreneur in the process of economic development at length. He imagines the entrepreneur as a creative, driven individual who finds "new combinations of [factors] of production” to develop a new product, corner a new market, or design a new technology. Schumpeter speculates about the psyche of the archetypal entrepreneur: he is motivated by a "dream to find a private kingdom, or dynasty...[driven by] the impulse to fight, to prove oneself superior to others, to succeed for the sake of...success itself” (p. XX).

In mainstream economics however, entrepreneurship has never played a central role. For decades, the main focus of economics has been on the allocation of resources and how it is achieved by markets or by governments. It is only recently with the revival of interest in the question of economic growth that Schumpeter's views have acquired greater salience. Empirical research on entrepreneurship in economics is surprisingly limited.

The current project asks why entrepreneurship thrives in certain societies and not in others. Social scientists have proposed many possible explanations to account for cross-country differences. A major body of research in economic development has emphasized the role of credit constraints making it impossible for the poor to borrow to set up their own businesses (Banerjee and Newman, 1993). The literature on transition from socialism to capitalism has emphasized the importance of institutions securing property rights (see e.g., Johnson, McMillan and Woodruff, 2002; Roland, 2000, Che and Qian, 1997) and the nefarious role of predatory behavior by government bureaucrats (Djankov et al., 2002), and organized crime (Frye and Zhuravskaya, 2000, Roland and Verdier, 2003). Security of property rights is also an increasingly important theme in the development literature (Acemoglu et al., 2002; De Soto, 2000; Besley, 1995). Surprisingly little is known about the personal characteristics of entrepreneurs, with one recent exception. Lazear (2002) conducted a survey of Stanford University MBA graduates and found that those with a higher number of jobs and shorter job tenures before graduate school were most likely to become entrepreneurs afterwards. He 
concludes that individuals who become entrepreneurs have a special ability to acquire general skills, which they then apply to their own businesses. Sociologists have long emphasized the role of values (Cochran, 1971) and social networks (Young, 1971) in promoting or discouraging entrepreneurial activities, while psychologists have hypothesized about the psychological traits associated with entrepreneurship - such as a personal need for achievement (McClellan, 1961), belief in the effect of personal effort on outcomes (McGhee and Crandall, 1968; Lao, 1970), attitudes towards risk, and individual self-confidence (Liles, 1974).

There is also no clear consensus in economics, or across the social sciences more broadly, on the institutional determinants of entrepreneurship. But policies to relax credit constraints will not be very helpful if insecurity of property rights is the main obstacle to entrepreneurship, and similarly, financial and legal reforms may not achieve much if the roots of entrepreneurship lie in cultural factors or even personality. How to promote entrepreneurship is still a mystery.

The goal of this project is to provide new empirical evidence on the determinants of entrepreneurship, with a focus on countries in transition from socialism, and less developed countries, settings where we believe entrepreneurship is likely to play a bigger role in economic growth. We have conducted surveys of both entrepreneurs and non-entrepreneurs in order to understand how these groups differ in terms of their individual characteristics, their skills, education, intellectual and personality traits, family background, social origins, social networks, values and beliefs, and in their perception of the institutional, social and economic environment businesses face. The plan is to conduct such surveys in five large countries - Russia, China, Nigeria, Brazil and India - and to exploit the substantial regional variation in institutions and culture within those countries. Identical questions will be asked across the different countries to ease cross-country comparisons, and to enable us to draw broad conclusions for developing countries as a whole.

In this paper, we report results from a pilot survey conducted in Russia in 2003-2004. We find suggestive evidence that social network effects play a large role in determining entrepreneurial behavior: those individuals whose relatives and childhood friends are entrepreneurs are more likely to be entrepreneurs - although this result should be interpreted with caution due to the likelihood of well-known omitted variable biases in the estimation of social effects (see Manski, 1993). Individual characteristics including academic success and educational background, performance on a test of cognitive ability, personal confidence, greed, and willingness to take risks are also important determinants of entrepreneurship, echoing the claims of Schumpeter and others. In addition, as one would expect, certain aspects of the institutional environment play an important role in determining the scope for entrepreneurship in 
Russia. In the paper, we control for the differences in institutional environment and focus on the effect of individual characteristics.

The rest of the paper is organized as follows. Section 2 describes the survey data collection. Section 3 presents summary statistics on the differences between entrepreneurs and non-entrepreneurs in Russia. Section 4 reports the analysis of the determinants of entrepreneurship using probit and logit analysis. Section 5 concludes.

\section{The survey.}

The pilot study was performed in Moscow and six other cities in three different regions of Russia, in an attempt to understand entrepreneurship in a wide range of settings: Nizhny Novgorod and Dzershinsk in the Nizhegorodskaya oblast; Perm and Chaykovsly in the Permskaya oblast in the Urals and Rostov on the Don and Taganrog in the Rostovskaya oblast, in the Soutern Volga region. These regions were selected for the varying perceptions on the ease of doing business reported in previous enterprise surveys (CEFIR, 2003; FIAS, 2004).

Three surveys were conducted. We first surveyed a random sample of 400 entrepreneurs 50 in each of the six regional cities and 100 from Moscow - during September-October 2003. An entrepreneur was defined as the owner or co-owner of a business with five or more employees. Entrepreneurs were identified and surveyed by a premier Russian survey firm. The universe of entrepreneurs was defined using official government statistics, and the survey firm then selected the 400 respondents randomly using this sampling frame. The entrepreneur survey lasted for 40 minutes on average.

During February and March 2004, an additional 440 non-entrepreneurs - 55 in each of the same size cities, and 110 in Moscow - were interviewed using a similar survey instrument, and this survey lasted an average of 35 minutes. The sampling frame was individuals with listings in the phonebook, and so the very poor or those who choose not to be listed in the telephone book may be systematically underrepresented. Using this sampling frame, the respondents were chosen randomly conditional on matching the age, gender and educational attainment of entrepreneurs from the first survey. In other words, the proportion of men, women, people at various ages and with different levels of educational attainment are near-identical in the two surveys. We opted for this approach to ensure that broad demographic differences between entrepreneurs and non-entrepreneurs were not driving the results, but rather other factors. In addition to the non-entrepreneurs "matched" to the demographic characteristics of the entrepreneurs, 150 additional non-entrepreneurs were also surveyed without regard to there demographic characteristics (12 in each of the six cities and 25 in Moscow). 
Finally, the survey firm conducted a short survey among a random sample of 1200 respondents (with the same breakdown across cities) asking nine questions about their personal characteristics, including whether or not they are an entrepreneur. This data allow us to roughly determine the proportion of entrepreneurs across the study sites. We find considerable variation across cities, with the proportion of entrepreneurs in Moscow at 8\%, Nizhny Novgorod at 6\%, Dzershinsk 13.3\%, Perm 16\%, Chaikovsky 11.3\%, Rostov on Don 11.3\% and finally Taganrog at $18 \%$. The limited number of cities and regions in the pilot study makes it difficult to generalize about the impact of regional institutional and cultural differences on entrepreneurship. This is a topic we will explore in the larger survey, which will cover a wider range of regions in Russia and in other large developing countries.

\section{How do entrepreneurs compare to non-entrepreneurs?}

We first present descriptive statistics, focusing on differences in means between the entrepreneurs and non-entrepreneurs, controlling for individual age, gender, education, and town.

\section{[Table 1 here]}

Over $90 \%$ of the respondents are Russian, and there is no statistically significant difference in ethnic composition between entrepreneurs and non-entrepreneurs. Despite the claims of Weber (1905) and others, there is similarly no difference in religious beliefs between the two groups - though we were surprised in general to see that a large majority of respondents in once strongly atheistic Russia declared themselves to be religious believers. There are significantly more married people among entrepreneurs, and they have more children although the average number is quite low (1.3 instead of 1.2 ). $44.3 \%$ of entrepreneurs declare to have been in the top $10 \%$ of students in secondary school while the corresponding figure is $23.7 \%$ for nonentrepreneurs. This response suggests either that the sampled population is not representative or indicates overconfidence in the survey population - and an even higher level of overconfidence among entrepreneurs.

Consistent with the survey answers on academic performance, entrepreneurs scored significantly higher than non-entrepreneurs on a test of cognitive ability, focusing on short-term recall (available from the authors upon request). They also declare themselves to be in better health and practice more sports than non-entrepreneurs, although this is possibly due to their higher average income and wealth.

As in Lazear (2002), we find that entrepreneurs have higher number of distinct previous professional activities than non-entrepreneurs. Entrepreneurs also declare more often that they 
plan to move in the future. They also appear to have different personality characteristics with respect to risk: when asked whether they were willing to accept a risk-neutral gamble - win \$10 with $50 \%$ probability and lose $\$ 10$ with $50 \%$ probability $-77.3 \%$ of entrepreneurs responded positively versus 59.7\% among non-entrepreneurs, suggesting that entrepreneurs are more risktaking. Once again, the higher income and wealth levels among entrepreneurs may explain some of this difference.

Entrepreneurs are better off than non-entrepreneurs along a range of income and wealth proxies (Panel B): they spend a smaller proportion of their income on food, are more likely to own a home, as well as more likely to own a car and a computer ( $48 \%$ of non-entrepreneurs and $5 \%$ of entrepreneurs own neither a car nor a computer).

Regarding work-leisure substitution possibilities, responses to the question of whether the respondent would retire if they won 100 times or 500 times Russian GDP per capita were also strikingly different for the two groups: $8 \%$ (18\%) of entrepreneurs would choose to retire if they won 100 times (500 times) average income, while the corresponding figure for nonentrepreneurs is much higher, at 32\% (47\%), a difference of over 20\% (nearly 30\%). When asked why they would not retire despite the hypothesized huge windfall, the key reasons were not pecuniary: about $50 \%$ of entrepreneurs and $24 \%$ of non-entrepreneurs only said it was because they wanted more money, while more than $80 \%$ of entrepreneurs and $70 \%$ of nonentrepreneurs claimed it was because they like their work and nearly $70 \%$ of non-entrepreneurs said it was because they considered their work to serve a useful purpose - much higher rates than for non-entrepreneurs, which is 50\% (Panel C).

Interestingly, entrepreneurs claim to be both happier and more successful than nonentrepreneurs: while only slightly over $40 \%$ of non-entrepreneurs consider themselves successful, the comparable figure for entrepreneurs is $73 \%$.

Russian entrepreneurs and non-entrepreneurs also differ substantially in family background (Panel D). The families of entrepreneurs had more education, better jobs and were richer. In particular, a much higher proportion of the fathers and mothers of entrepreneurs had higher education, respectively $41.8 \%$ and $36.5 \%$, than the parents of non-entrepreneurs (24 and 20\%, respectively). Similarly, the parents of entrepreneurs were also significantly less likely to have been workers. Note that while fathers of entrepreneurs were more likely to have been a director or a boss (19\% for entrepreneurs versus $11 \%$ for non-entrepreneurs), the opposite is true for mothers (only 2.5\% versus $8 \%$ ). A significantly higher proportion of entrepreneurs' fathers nearly 50\% - were members of the Communist Party (compare with 35\% for non-entrepreneurs), although the difference is not significant for mothers of entrepreneurs and non-entrepreneurs. 
An even more striking difference concerns the social environment and social networks of the two groups. When asked whether at least one sibling, parent, uncle, aunt or cousin had been an entrepreneur, $99.8 \%$ of entrepreneurs responded positively while less than $50 \%$ of nonentrepreneurs have a relative who is an entrepreneur. Another striking pattern relates to friends during childhood and adolescence. Respondents were first asked to remember five friends from their childhood and adolescence, and then to report how many of these five have become entrepreneurs. The response is twice as high for entrepreneurs as for non-entrepreneurs (1.2 of 5 friends for entrepreneurs versus 0.6 friends for non-entrepreneurs). Clearly, entrepreneurship is strongly associated with having a family background of entrepreneurs and being in a social circle with many entrepreneurs. Making a causal claim about the effect of social interactions using observational cross-sectional survey data like the data we use is problematic because of the plausible presence of omitted variables that influence choices of individuals in a similar way as discussed by Manski (1993) and others. However, note that more than one quarter of entrepreneurs in our sample claim that friends who were entrepreneurs influenced their own choice to become an entrepreneur, further suggestive on the important role of the social environment and social effects in the entrepreneurship decision.

Cultural differences also appear to play some role - but less than some would have expected. Entrepreneurs appear to have a stronger work ethic than non-entrepreneurs on average: nearly three quarters of entrepreneurs consider work to be an important value compared to slightly over half of non-entrepreneurs (Table 2). Entrepreneurs believe that the work ethic is less widely held by the population of their town as a whole than it actually is (as shown in the final three columns in Table 2), perhaps evidence of contemptuous attitude towards non-entrepreneurs. Intellectual achievement is also more important to entrepreneurs (and apparently their families) than to nonentrepreneurs, as are power and politics. However, in many other dimensions entrepreneurs and non-entrepreneurs share similar values, for instance in terms of the proportion of respondents believing that family, friends, leisure time, religion, service to others, financial security, health, and freedom are important.

\section{[Table 2 here]}

In terms of social norms regarding corruption and cheating, both paying and receiving bribes are considered more acceptable by entrepreneurs than non-entrepreneurs (Table 3). It is unclear how to interpret this pattern in the data: while it could be interpreted to mean that Russian entrepreneurs on average have fewer scruples regarding corruption than non-entrepreneurs, it is also probably the case that many entrepreneurs are immersed in business environments where 
there frequently is corruption and have come to accept it as a part of doing business. There are no statistically significant differences between entrepreneurs and non-entrepreneurs, however, in two other hypothetical cheating measures, avoiding a fare on public transport and buying a stolen item. Both entrepreneurs and non-entrepreneurs appear to "project" their own views toward corruption on other people in their town.

[Table 3 here]

Entrepreneurs have more trust in business partners, employees and other business people then do non-entrepreneurs, again perhaps due to their experience in business, which could promote this sort of trust (Table 4). However, in terms of overall trust of friends, families, and others, entrepreneurs and non-entrepreneurs are largely similar, whether the trust question is asked in terms of general trust, or with reference to trusting individuals in particular situations (results not shown).

\section{[Table 4 here]}

There were also survey questions regarding respondents' subjective perceptions of the attitude that the population as a whole, and different government officials, have towards entrepreneurs. Subjective perceptions are important, since they often shape economic choices. In general, perhaps surprisingly, entrepreneurs and non-entrepreneurs appear to have very similar perceptions in this dimension, with a few exceptions, mostly notably less willingness among entrepreneurs to use the courts to punish a government official who abuses her / his power, and a stronger belief among entrepreneurs that it is easy to find money to start an enterprise (Table 5).

[Table 5 here]

In summary, there are significant differences between Russian entrepreneurs and nonentrepreneurs along many personality (self-confidence and risk accepting behavior) and other characteristics (cognitive ability), in terms of certain cultural values (work ethic), as well as in their family and social background, in particular the high density of entrepreneurs among their family and friends. Fewer differences are seen in views on the business environment and the ability to trust others.

\section{Determinants of entrepreneurship}


To understand the determinants of entrepreneurship, we focus on variables that can plausibly be considered exogenous to the decision to become an entrepreneur.

[Table 6 here]

Higher levels of parents' education are significantly positively associated with entrepreneurship in a probit specification (Table 6, first three regressions). The children of fathers who were members of the Communist Party are also significantly more likely to become entrepreneurs. Interpretation of this effect is complicated - more motivated and ambitious men might have been more likely to have joined the Party, and also are likely to have more motivated children. On the other hand, children of Party members may have inherited a more extensive social network of business and government contacts that might have smoothed the operation of an enterprise. Interestingly, having had a mother being a boss or a director has a negative effect on entrepreneurship, although the reasons why remain obscure. Having entrepreneurs in the family and among adolescent friends also has an important effect, although once again interpreting this as a causal effect is complicated by well-known identification problems.

The individual characteristics with strongest predictive power is the individual's score on the cognitive exam (testing recall), while other individual characteristics, including height and risktaking, do not have a robust effect on becoming an entrepreneur. Family characteristics remain statistically significant when other individual characteristics are included. The economic significance of the results is as follows: all else constant, father's and mother's higher education increase the probability to become an entrepreneur by 6 and 21 percentage points, respectively; presence of a businessperson in the family and among adolescent friends leads to an increase of this probability of 6 and 4 percentage points, respectively. Town fixed effects control for the actual differences in institutional environment; they are highly significant. Yet, the individual perceptions of business climate matter for career choice: lower perceived corruption and better perceived attitude of population and government towards entrepreneurship increases the probability to become entrepreneur. (In all regressions, inclusion of the measures of individual perceptions of the business climate do not have a significant effect on estimates of other coefficients). Results are similar when the dependent variable is years since the individual became an entrepreneur (Table 6, regression 4). This variable is best interpreted as an early start as an entrepreneur, right at the beginning of transition, or even before then in the shadow economy. Taken together, the picture that emerges is that a whole set of factors determine the 
development of entrepreneurship in Russia: education, social network effects, as well as individual characteristics such as cognitive ability.

One potential problem with this analysis is that there are different types of business owners who became entrepreneurs due to varying circumstances. We asked respondents questions about those circumstances. The two major categories that come out are what we call entrepreneur by opportunity and entrepreneur by necessity. The former became business owners because they seized a business opportunity, in the Schumpeterian sense, they are the only true entrepreneurs. The latter became business owners primarily because they lost their job or because of economic decline in their previous sector. Note that other motives such as having obtained money play a relatively minor role in the response to that question. Table 7 reports probit analysis on these two different types of business owners. We report the regressions with only family and social characteristics, with only individual characteristics and both together. Institutional variables were included in all specifications.

\section{[Table 7 here]}

Such variables as father's party membership, mother's education and career, cognitive ability, and greed have the same effect on probability to become a business owner of both types . The father's education has a negative effect for entrepreneurs by necessity but party membership of the father has twice as strong effect on chances to become entrepreneurs by necessity compared to entrepreneurs by opportunity. The family network has a positive effect only on probability to become "an opportunity entrepreneur," this variable has a negative effect on entrepreneurs by necessity. Perceived favorable attitude of government officials towards entrepreneurs increases chances of taking an business opportunity and reduces chances to open own business due to necessity.

We also run a multinomial logit regression on the choice of becoming entrepreneurs by opportunity, by necessity, or not starting own business (not reported). The results are only slightly different. Mother's background, greed, perceived attitude of population towards entrepreneurs, and perceived corruption are the most robust effects to the choice of specification and across types of entrepreneurs. Family network and perceived attitude of the government have positive effect on becoming a business owner of both types, but the effects are significantly larger on entrepreneurs by opportunity. Risk-taking has a negative effect for entrepreneurs by necessity and a positive effect on entrepreneurs by opportunity. All in all, family and perceived business climate seem to play less of a role in entrepreneurship by necessity. 
Finally, we asked non-entrepreneurs the reasons why they did not want to become entrepreneurs (Table 8). The three main reasons that stand out are lack of money, lack of entrepreneurial skills ("I do not have what it takes") and risk aversion towards entrepreneurial activity. The last two point towards individual characteristics whereas lack of money can be interpreted as credit constraints but also as lack of drive to find the money, which is also an individual characteristic. It seems that individual characteristics play an important role in the choice to become or not an entrepreneur. Confidence in starting one's own business is boosted by having entrepreneurs in one’s family and among one’s friends.

[Table 8 here]

\section{Conclusions}

Preliminary results suggest that the determinants of entrepreneurship in Russia are multiple. Russian entrepreneurs are driven by their work, they like to take risks and are greedy. Social network effects - having entrepreneurs in the family and among one's friends - appear important for the choice to become an entrepreneur. Individual characteristics are the most important, in particular cognitive ability, risk-taking and greed. Cultural differences do not seem to play a key role in Russia, even though there are some notable differences between entrepreneurs and nonentrepreneurs, including their self-expressed work ethic. Credit constraints appear to play some role in discouraging people from starting or expanding an enterprise but they are only one factor among others.

The current survey does not allow to differentiate the precise channels through which social network effects influence the choice to become an entrepreneur. Are there hidden characteristics in entrepreneurial families that create a sorting effect to create clusters of social networks of entrepreneurs? Are there peer effects - or simply reflects social sorting? To the extent that there are network effects, what are these about? Do they merely alleviate credit constraints? Do they serve as encouragement and create herding effects? Are they the locus of exchange of business information and skills that have significant value for entrepreneurs? We are refining our survey to give a better answer to those questions. In the meanwhile, we hope to discover whether responses in other developing economies are similar or different to what we found in Russia. In addition, the data from the Russian pilot alone are insufficient to evaluate the effect of institutional variables on entrepreneurship because of too few town-level observations. One of the tasks of the larger survey is to compare the importance of individual and institutional effects. 
References

Acemoglu, D. J Robinson and S. Johnson (2001) "The Colonial Origins of Comparative Development: An Empirical Investigation”, American Economic Review, volume 91, pp. 1369-1401.

Aghion, Ph. And P. Howitt (1997) Endogenous Growth Theory, MIT Press, Cambridge Massachussetts.

Banerjee, A. and A. Newman (1993) "Occupational Choice and the Process of Development" Journal of Political Economy, 101(2).

Besley, T. (1995). "Property Rights and Investment Incentives: Theory and Evidence from Ghana," Journal of Political Economy, Vol. 103 (5) pp. 903-37

Che, J. and Y. Qian 1997

Cochran, T. (1971) “The Entrepreneur in Economic Change”, in Entrepreneurship and Economic Development, The Free Press.

De Soto, H. (2000) The Mystery of Capital: Why Capitalism Triumphs in the West and Fails Everywhere Else, Harper \& Row.

Djankov et al. (2002) “The Regulation of Entry” Quarterly Journal of Economics, 1-37.

Frye, T. and E. Zhuravskaya (2000) "Rackets, Regulation and the Rule of Law," Journal of Law, Economics, and Organization, Vol. 16 (2) pp. 478-502.

Johnson, S., J. McMillan and C. Woodruff, (2002) "Property Rights and Finance," American Economic Review, 92 (5) pp. 1335-1356.

Lao, R.C. (1970) "Internal-External Control and Competent and Innovative Behavior among Negro College Students”, Journal of Personality and Social Psychology.

Liles, P.R. (1971) New Business Ventures and The Entrepreneur, Richard D. Irwin.

McClelland, D. (1961), The Achieving Society, Princeton: D. Van Nostrand.

McGhee, P.E and V.C. Crandall. (1968) "Beliefs in Internal-External Control of Reinforcement and Academic Performance”, Child Development.

Roland, G. (2000) Transition and Economics. Politis, Markets and Firms. MIT Press, Cambridge Massachusetts.

Roland, G. and T. Verdier (2003) "Law Enforcement and Transition”, European Economic Review.

World Bank, (2003) Doing Business in 2004: Understanding Regulation, Oxford University Press.

Young, Frank W. (1971) “A Macrosociological Interpretation of Entrepreneurship”, in Entrepreneurship and Economic Development, The Free Press. 
Table 1 : Differences between entrepreneurs and non-entrepreneurs

\begin{tabular}{|c|c|c|c|c|c|}
\hline \multirow{2}{*}{ Panel A: Individual characteristics } & \multicolumn{2}{|c|}{$\begin{array}{l}\text { Entrepreneurs } \\
\text { (E) }\end{array}$} & \multicolumn{2}{|c|}{$\begin{array}{l}\text { Non- } \\
\text { entrepreneurs } \\
\quad(\mathrm{NE})\end{array}$} & $\begin{array}{l}\text { Significance of } \\
\text { difference }\end{array}$ \\
\hline & & & & & \\
\hline Russian nationality, \% & 90.3 & [1.4] & 90.5 & {$[1.4]$} & \\
\hline Religious believer, \% & 60.0 & [3.6] & 55.8 & [3.6] & \\
\hline Married, \% & 74.0 & {$[4.0]$} & 63.2 & {$[4.0]$} & $* * \star$ \\
\hline Number of children, \% & 134.3 & [3.7] & 116.8 & [3.7] & $* * *$ \\
\hline Were you in the top $10 \%$ in secondary school? $\%$ & 44.3 & {$[3.3]$} & 23.7 & [3.3] & $* \star \star$ \\
\hline Cognitive ability test score & 5.0 & {$[0.2]$} & 4.4 & {$[0.2]$} & *** \\
\hline Speak foreign languages, \% & 37.5 & [5.3] & 35.5 & [5.3] & \\
\hline Number of previous professional activities & 1.8 & {$[0.2]$} & 1.4 & {$[0.2]$} & * \\
\hline Number of localities lived & 1.4 & {$[0.1]$} & 1.1 & {$[0.1]$} & ** \\
\hline Plan to move, $\%$ & 4.5 & {$[2.0]$} & 2.3 & {$[2.0]$} & \\
\hline Accept a risk-neutral gamble (+/- $\$ 10$ or $\$ 20), \%$ & 77.3 & {$[5.4]$} & 59.7 & {$[5.4]$} & *** \\
\hline Good or very good health (self-described), \% & 76.3 & [3.1] & 66.4 & [3.1] & $* * \star$ \\
\hline Practice sports (regularly or from time to time), \% & 45.0 & {$[5.9]$} & 25.0 & {$[5.9]$} & $* \star \star$ \\
\hline Overweight or obese, \% & 15.3 & [2.6] & 15.6 & [2.6] & \\
\hline \multicolumn{6}{|l|}{ Panel B: Proxies for Income and wealth } \\
\hline Spend more than half of income on food, \% & 12.3 & {$[4.4]$} & 46.9 & {$[4.4]$} & $* * *$ \\
\hline Own a house, \% & 47.0 & {$[5.2]$} & 31.4 & [5.2] & $* * *$ \\
\hline Own a car, \% & 84.5 & {$[4.3]$} & 39.3 & {$[4.3]$} & *** \\
\hline Own a computer, \% & 82.0 & {$[9.3]$} & 35.5 & {$[9.3]$} & *** \\
\hline \multicolumn{6}{|l|}{ Panel C: Motivation, greed and happiness } \\
\hline Would retire if won 100 times GDP per capita, \% & 8.0 & [2.8] & 31.9 & [2.8] & $* * \star$ \\
\hline Would retire if won 500 times GDP per capita, \% & 18.0 & [3.9] & 47.0 & [3.9] & $* \star \star$ \\
\hline $\begin{array}{l}\text { Why not retire if earned } 500 \text { times GDP per capita } \\
\text { (among those replying would not retire; several } \\
\text { answers permitted) }\end{array}$ & & & & & \\
\hline - I like what I do, \% & 81.9 & [3.0] & 70.2 & [3.0] & *** \\
\hline - I want more money, \% & 49.2 & [3.3] & 24.2 & [3.3] & *** \\
\hline - My work serves a useful social purpose, \% & 69.5 & [4.3] & 49.7 & [4.3] & $* * *$ \\
\hline Very happy or quite happy in life, \% & 90.8 & [3.9] & 71.7 & [3.9] & $* * \star$ \\
\hline Very successful or quite successful in life, \% & 72.8 & {$[4.2]$} & 43.5 & {$[4.2]$} & *** \\
\hline
\end{tabular}


Table 1(continued):

\begin{tabular}{|c|c|c|c|c|c|}
\hline & \multicolumn{2}{|c|}{$\begin{array}{l}\text { Entrepreneurs } \\
\text { (E) }\end{array}$} & \multicolumn{2}{|c|}{$\begin{array}{l}\text { Non- } \\
\text { entrepreneurs } \\
\text { (NE) }\end{array}$} & $\begin{array}{l}\text { Significance of } \\
\text { difference }\end{array}$ \\
\hline \multicolumn{6}{|l|}{ Panel D: Sociological characteristics } \\
\hline Father had higher education, \% & 41.8 & [3.4] & 24.0 & [3.4] & *** \\
\hline Father was a boss or director, $\%$ & 19.0 & [3.1] & 11.4 & [3.1] & ** \\
\hline Father was a worker, $\%$ & 36.2 & {$[4.0]$} & 50.1 & [4.0] & *** \\
\hline Father was a member of the communist party, \% & 47.9 & [1.9] & 35.0 & [1.9] & *** \\
\hline Mother had higher education, \% & 36.5 & {$[4.2]$} & 19.6 & [4.2] & *** \\
\hline Mother was a boss or director, \% & 2.5 & [1.6] & 8.1 & [1.6] & *** \\
\hline Mother was a worker, \% & 25.9 & [5.1] & 46.7 & [5.1] & *** \\
\hline Mother was a member of the communist party, \% & 18.8 & [3.7] & 17.9 & [3.7] & \\
\hline Parent wealth when you were 16 was above average, \% & 51.6 & [6.3] & 41.0 & [6.3] & * \\
\hline Were members of your family running a business? \% & 99.8 & [9.5] & 46.2 & {$[9.5]$} & *** \\
\hline $\begin{array}{l}\text { Number of } 5 \text { childhood friends who became } \\
\text { entrepreneurs }\end{array}$ & 1.2 & {$[0.1]$} & 0.6 & {$[0.1]$} & *** \\
\hline $\begin{array}{l}\text { How many of high school / university friends became } \\
\text { entrepreneurs? }\end{array}$ & 1.2 & {$[0.1]$} & 0.5 & [0.1] & *** \\
\hline
\end{tabular}

Notes: For non-entrepreneurs we report means conditional on non-entrepreneurs having the same distribution over town, age, gender, and education as entrepreneurs. Robust standard errors adjusted for clustering at the town level are in brackets. ${ }^{*},{ }^{* *}$ and ${ }^{* * *}$ respectively denote $10 \%, 5 \%$ and $1 \%$ significance levels. 
Table 2: Comparing the values of entrepreneurs and non-entrepreneurs

\begin{tabular}{|c|c|c|c|c|c|c|c|c|c|}
\hline \multirow[t]{2}{*}{$\begin{array}{l}\text { The following is very } \\
\text { important in life for: }\end{array}$} & \multicolumn{3}{|c|}{ Respondent } & \multicolumn{3}{|c|}{$\begin{array}{l}\text { Respondent's } \\
\text { family }\end{array}$} & \multicolumn{2}{|c|}{$\begin{array}{l}\text { Other people } \\
\text { (according to } \\
\text { respondent) }\end{array}$} & \\
\hline & E, \% & NE, \% & & E, \% & NE, \% & & E, \% & $\mathrm{N}, \%$ & \\
\hline \multirow[t]{2}{*}{ Work } & 74.3 & 54.8 & & 46.8 & 49.5 & & 35.5 & 50.4 & \\
\hline & [3.9] & [3.9] & & [5.0] & [5.0] & & [4.6] & [4.6] & \\
\hline \multirow[t]{2}{*}{ Politics } & 8.3 & 3.6 & 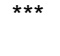 & 7.8 & 3.9 & 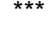 & 10.8 & 6.7 & \\
\hline & [1.3] & [1.3] & & [1.5] & [1.5] & & [3.8] & [3.8] & \\
\hline \multirow[t]{2}{*}{ Power } & 10.3 & 5.4 & ** & 10.8 & 7.7 & ** & 20.3 & 17.5 & \\
\hline & [2.4] & [2.4] & & [1.3] & [1.3] & & [4.3] & [4.3] & \\
\hline \multirow[t]{2}{*}{ Intellectual achievement } & 42.3 & 35.1 & *夫 & 23.8 & 24.9 & & 7.0 & 10.6 & * \\
\hline & [3.6] & [3.6] & & [3.1] & [3.1] & & {$[1.9]$} & [1.9] & \\
\hline \multirow[t]{2}{*}{ Freedom } & 61.5 & 53.5 & & 40.8 & 44.8 & & 34.8 & 40.1 & *夫 \\
\hline & [4.9] & [4.9] & & [3.3] & [3.3] & & [2.5] & [2.5] & \\
\hline \multirow[t]{2}{*}{ Family } & 84.3 & 81.2 & & 83.0 & 83.8 & & 42.5 & 57.1 & 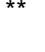 \\
\hline & [2.1] & [2.1] & & {$[4.8]$} & {$[4.8]$} & & {$[6.7]$} & {$[6.7]$} & \\
\hline \multirow[t]{2}{*}{ Health } & 75.0 & 80.8 & & 74.8 & 77.2 & & 49.3 & 58.6 & \\
\hline & {$[4.0]$} & {$[4.0]$} & & [2.5] & [2.5] & & [6.5] & [6.5] & \\
\hline \multirow[t]{2}{*}{ Service to others } & 20.8 & 19.5 & & 14.0 & 13.6 & & 5.0 & 7.8 & \\
\hline & [3.3] & [3.3] & & [2.2] & [2.2] & & [3.5] & [3.5] & \\
\hline \multirow[t]{2}{*}{ Financial security } & 52.8 & 51.2 & & 52.8 & 55.6 & & 54.0 & 57.8 & \\
\hline & [4.3] & [4.3] & & {$[5.0]$} & [5.0] & & [3.1] & [3.1] & \\
\hline \multirow[t]{2}{*}{ Friends } & 42.5 & 43.8 & & 34.3 & 38.8 & & 25.5 & 32.3 & * \\
\hline & {$[4.0]$} & {$[4.0]$} & & [3.4] & [3.4] & & [3.6] & [3.6] & \\
\hline \multirow[t]{2}{*}{ Leisure time } & 22.8 & 21.8 & & 19.5 & 19.6 & & 17.8 & 20.2 & \\
\hline & [3.9] & [3.9] & & [4.7] & [4.7] & & [2.1] & [2.1] & \\
\hline \multirow[t]{2}{*}{ Religion } & 12.0 & 12.1 & & 7.3 & 7.7 & & 4.8 & 4.8 & \\
\hline & [2.9] & [2.9] & & [2.1] & [2.1] & & [2.5] & [2.5] & \\
\hline
\end{tabular}

Notes: For non-entrepreneurs we report means conditional on non-entrepreneurs having the same distribution over town, age, gender, and education as entrepreneurs. Robust standard errors adjusted for clustering at the town level are in brackets. ${ }^{*},{ }^{* *}$ and ${ }^{* * *}$ respectively denote $10 \%, 5 \%$ and $1 \%$ significance levels for the difference in conditional means.

Table 3: Values on legal social norms

\begin{tabular}{lccccc}
\hline The following can be justified by: & \multicolumn{2}{c}{ Respondent } & \multicolumn{2}{c}{ Other people (according } \\
& \multicolumn{2}{c}{ to respondent) } \\
& E, \% & NE, \% & \multicolumn{2}{c}{ E, \% } & N, \% \\
\hline Paying a bribe to a government official & 53.3 & 39.3 & & 54.5 & 42.4 \\
& {$[6.7]$} & {$[6.7]$} & $* *$ & {$[7.2]$} & {$[7.2]$} \\
Accepting a bribe & 31.8 & 20.8 & & 38.5 & 27.2 \\
& {$[3.9]$} & {$[3.9]$} & {$[5.0]$} & {$[5.0]$} \\
Avoiding a fare on public transport & 75.8 & 79.3 & 76.8 & 76.2 \\
& {$[4.7]$} & {$[4.7]$} & {$[7.2]$} & {$[7.2]$} \\
Buying something you know was stolen & 22.8 & 23.8 & 36.8 & 28.1 \\
& {$[4.2]$} & {$[4.2]$} & {$[8.1]$} & {$[8.1]$} \\
\hline
\end{tabular}

Notes: For non-entrepreneurs we report means conditional on non-entrepreneurs having the same distribution over town, age, gender, and education as entrepreneurs. Robust standard errors adjusted for clustering at the town level are in brackets. ${ }^{*},{ }^{* *}$ and ${ }^{* * *}$ respectively denote $10 \%, 5 \%$ and $1 \%$ significance levels for the difference in conditional means. 
Table 4: Self-expressed trust of others

\begin{tabular}{lccccc}
\hline Have a lot of trust in: & \multicolumn{5}{c}{ Respondent } \\
& E, \% & NE, \% & \\
\hline Family members & 89.5 & {$[3.0]$} & 86.3 & {$[3.0]$} & \\
Friends & 49.0 & {$[3.2]$} & 45.0 & {$[3.2]$} & \\
Business partners & 25.5 & {$[2.4]$} & 16.5 & {$[2.4]$} & $* *$ \\
Employees & 10.8 & {$[1.9]$} & 6.9 & {$[1.9]$} & $* *$ \\
Other business people & 3.0 & {$[0.9]$} & 1.1 & {$[0.9]$} & \\
Local government officials & 1.0 & {$[0.3]$} & 0.8 & {$[0.3]$} & \\
Regional government officials & 1.0 & {$[0.6]$} & 0.9 & {$[0.6]$} & \\
Central government officials & 1.5 & {$[0.5]$} & 1.3 & {$[0.5]$} & \\
Other people in town & 2.5 & {$[1.0]$} & 0.8 & {$[1.0]$} & $*$ \\
Russian people & 1.8 & {$[0.5]$} & 0.8 & {$[0.5]$} & $*$ \\
Foreigners & 1.0 & {$[0.7]$} & 1.2 & {$[0.7]$} & \\
\hline
\end{tabular}

Notes: For non-entrepreneurs we report means conditional on non-entrepreneurs having the same distribution over town, age, gender, and education as entrepreneurs. Robust standard errors adjusted for clustering at the town level are in brackets. ${ }^{*},{ }^{* *}$ and ${ }^{* * *}$ respectively denote $10 \%, 5 \%$ and $1 \%$ significance levels for the difference in conditional means.

Table 5: Perceptions of the institutional environment

\begin{tabular}{llllll}
\hline & \multicolumn{5}{c}{ Respondent } \\
\hline & \multicolumn{3}{c}{ E, \% } & \multicolumn{3}{c}{ NE, \% } \\
\hline People in your town are favorable towards entrepreneurs & 66.0 & {$[5.7]$} & 65.0 & {$[5.7]$} & \\
Local government is favorable towards entrepreneurs & 48.0 & {$[6.3]$} & 50.1 & {$[6.3]$} \\
Regional government is favorable towards entrepreneurs & 49.0 & {$[7.6]$} & 47.0 & {$[7.6]$} \\
Central government is favorable towards entrepreneurs & 54.5 & {$[6.8]$} & 51.5 & {$[6.8]$} & \\
Go to court if cheated by supplier or client & 65.8 & {$[4.2]$} & 76.2 & {$[4.2]$} & $* *$ \\
Go to court if government official abuses power & 61.5 & {$[3.1]$} & 74.0 & {$[3.1]$} & $*$ \\
Private entrepreneurs pay bribes to avoid regulations & 66.5 & {$[3.5]$} & 64.7 & {$[3.5]$} \\
Private entrepreneurs pay bribes to change rules & 49.8 & {$[6.2]$} & 51.0 & {$[6.2]$} & $*$ \\
It is relatively easy in town to find money to start business & 21.0 & {$[3.3]$} & 13.2 & {$[3.3]$} & \\
Most people in town can be trusted & 16.0 & {$[4.0]$} & 16.5 & {$[4.0]$} & \\
\hline
\end{tabular}

Notes: For non-entrepreneurs we report means conditional on non-entrepreneurs having the same distribution over town, age, gender, and education as entrepreneurs. Robust standard errors adjusted for clustering at the town level are in brackets. ${ }^{*},{ }^{* *}$ and ${ }^{* * * *}$ respectively denote $10 \%, 5 \%$ and $1 \%$ significance levels for the difference in conditional means. 
Table 6 : Entrepreneurship and entrepreneurial experience

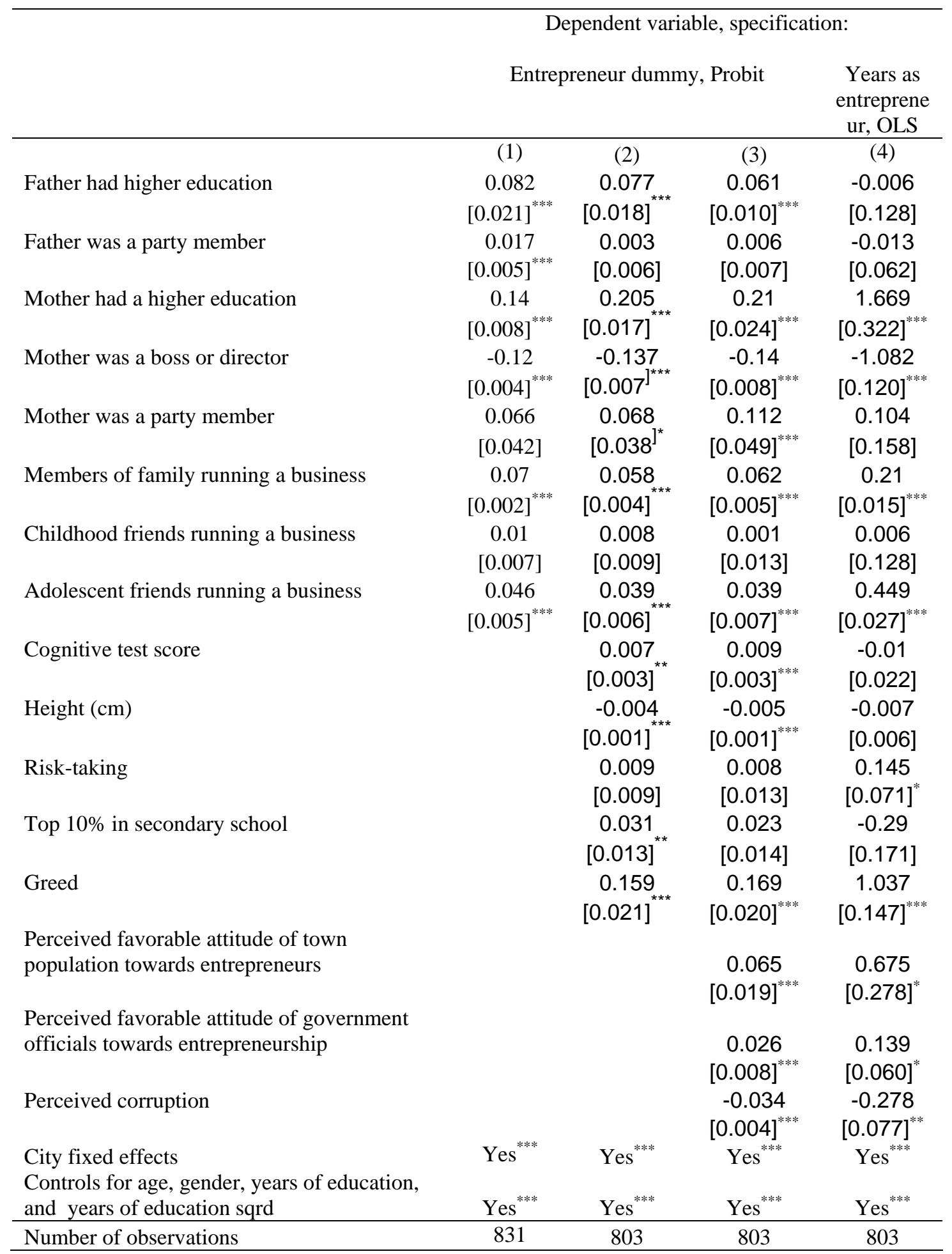

Notes: In regressions 1-3 the marginal effects are presented. Robust standard errors adjusted for clustering at the town level are in brackets. ${ }^{* * *}$ and ${ }^{* * *}$ respectively denote $10 \%, 5 \%$ and $1 \%$ significance levels. 
Table 7. Entrepreneurs, by opportunity or by necessity

\begin{tabular}{|c|c|c|c|c|c|c|}
\hline \multirow{2}{*}{ Father had higher education } & \multicolumn{3}{|c|}{ By opportunity } & \multicolumn{3}{|c|}{ By necessity } \\
\hline & 0.04 & & 0.034 & -0.042 & & -0.049 \\
\hline & {$[0.004]^{* * *}$} & & {$[0.006]^{* * *}$} & {$[0.002]^{* * *}$} & & {$[0.003]^{* * *}$} \\
\hline \multirow[t]{2}{*}{ Father was a party member } & 0.029 & & 0.022 & 0.046 & & 0.051 \\
\hline & {$[0.008]^{* * *}$} & & {$[0.008]^{* * *}$} & {$[0.002]^{* * *}$} & & {$[0.004]^{* * *}$} \\
\hline \multirow[t]{2}{*}{ Mother had a higher education } & 0.004 & & 0.029 & 0.024 & & 0.04 \\
\hline & [0.009] & & {$[0.004]^{* * *}$} & {$[0.006]^{* * *}$} & & {$[0.004]^{* * *}$} \\
\hline \multirow[t]{2}{*}{ Mother was a boss or director } & -0.043 & & -0.043 & -0.058 & & -0.059 \\
\hline & {$[0.003]^{* * *}$} & & {$[0.005]^{* * *}$} & {$[0.005]^{* * *}$} & & {$[0.004]^{* * *}$} \\
\hline \multirow[t]{2}{*}{ Mother was a party member } & 0.045 & & 0.05 & 0.032 & & 0.034 \\
\hline & {$[0.020]^{* * *}$} & & {$[0.021]^{* *}$} & {$[0.011]^{* * *}$} & & {$[0.010]^{* * *}$} \\
\hline \multirow[t]{2}{*}{ Members of family running a business } & 0.058 & & 0.052 & -0.002 & & -0.006 \\
\hline & {$[0.001]^{* * *}$} & & {$[0.002]^{* * *}$} & [0.003] & & {$[0.003]^{* *}$} \\
\hline \multirow[t]{2}{*}{ Childhood friends running a business } & 0.023 & & 0.024 & 0.007 & & 0.006 \\
\hline & {$[0.004]^{* * *}$} & & {$[0.004]^{* * *}$} & {$[0.003]^{* *}$} & & [0.005] \\
\hline \multirow[t]{2}{*}{ Adolescent friends running a business } & 0.011 & & 0.004 & 0.019 & & 0.02 \\
\hline & {$[0.006]^{*}$} & & [0.006] & {$[0.002]^{* * *}$} & & {$[0.001]^{* * *}$} \\
\hline \multirow[t]{2}{*}{ Cognitive ability } & & 0.016 & 0.008 & & 0.003 & 0.005 \\
\hline & & {$[0.001]^{* * *}$} & {$[0.001]^{* * *}$} & & {$[0.001]^{* * *}$} & {$[0.001]^{* * *}$} \\
\hline \multirow[t]{2}{*}{ height (cm) } & & -0.001 & -0.001 & & -0.002 & -0.002 \\
\hline & & [0.001] & {$[0.001]^{* * *}$} & & {$[0.001]^{* *}$} & {$[0.000]^{* * *}$} \\
\hline \multirow[t]{2}{*}{ risk-taking } & & 0.015 & -0.015 & & 0.02 & -0.019 \\
\hline & & [0.011] & [0.011] & & {$[0.002]^{* * *}$} & {$[0.006]^{* * *}$} \\
\hline \multirow[t]{2}{*}{ Above $10 \%$ in secondary school } & & 0 & -0.03 & & 0.015 & 0.006 \\
\hline & & [0.008] & {$[0.011]^{* * *}$} & & {$[0.002]^{* * *}$} & {$[0.002]^{* * *}$} \\
\hline \multirow[t]{2}{*}{ Greed } & & 0.187 & 0.166 & & 0.054 & 0.029 \\
\hline & & {$[0.006]^{* * *}$} & {$[0.007]^{* * *}$} & & {$[0.006]^{* * *}$} & {$[0.011]^{* * *}$} \\
\hline \multirow{2}{*}{$\begin{array}{l}\text { Perceived favorable attitude of town } \\
\text { population towards entrepreneurs }\end{array}$} & & & & & & \\
\hline & $\begin{array}{c}0.087 \\
{[0.014]^{* * *}}\end{array}$ & $\begin{array}{c}0.071 \\
{[0.015]^{* * *}}\end{array}$ & $\begin{array}{c}0.096 \\
{[0.015]^{* * *}}\end{array}$ & $\begin{array}{c}0.018 \\
{[0.005]^{* * *}}\end{array}$ & $\begin{array}{c}0.024 \\
{[0.010]^{* *}}\end{array}$ & $\begin{array}{c}0.025 \\
{[0.006]^{* * *}}\end{array}$ \\
\hline \multicolumn{7}{|l|}{$\begin{array}{l}\text { Perceived favorable attitude of } \\
\text { government officials towards }\end{array}$} \\
\hline \multirow[t]{2}{*}{ entrepreneurship } & 0.009 & 0.006 & 0.01 & -0.004 & -0.012 & -0.004 \\
\hline & {$[0.004]^{* *}$} & {$[0.003]^{* * *}$} & {$[0.005]^{* * *}$} & {$[0.002]^{* *}$} & {$[0.002]^{* * *}$} & {$[0.002]^{*}$} \\
\hline \multirow[t]{2}{*}{ Perceived corruption } & -0.03 & -0.033 & -0.034 & -0.014 & -0.017 & -0.015 \\
\hline & {$[0.013]^{*}$} & {$[0.016]$} & {$[0.013]^{* *}$} & {$[0.008]$} & [0.011] & [0.007] \\
\hline City fixed effects & Yes $^{* * *}$ & Yes $^{* * *}$ & $\mathrm{Yes}^{* * *}$ & Yes $^{* * *}$ & $\mathrm{Yes}^{* * *}$ & $\mathrm{Yes}^{* * *}$ \\
\hline $\begin{array}{l}\text { Controls for age, gender, years of } \\
\text { education, and years of education sqrd }\end{array}$ & Yes $^{* * *}$ & Yes $^{* * *}$ & Yes $^{* * *}$ & Yes $^{* * *}$ & Yes $^{* * *}$ & Yes $^{* * *}$ \\
\hline Observations & 831 & 922 & 803 & 831 & 922 & 803 \\
\hline
\end{tabular}

Notes: All specifications are Probits, with the marginal effects reported. Robust standard errors adjusted for clustering at the town level are in brackets. ${ }^{*},{ }^{* *}$ and ${ }^{* * *}$ respectively denote $10 \%, 5 \%$ and $1 \%$ significance levels. 
Table 8. The reasons for not running own business (Percentage of people who indicated that the following is the reason)

\begin{tabular}{|c|c|c|c|c|}
\hline & \multicolumn{2}{|c|}{$\begin{array}{l}\text { The one main } \\
\text { reason }\end{array}$} & \multicolumn{2}{|c|}{$\begin{array}{l}\text { All reasons } \\
\text { that apply }\end{array}$} \\
\hline & $\%$ & SE & $\%$ & $\mathrm{SE}$ \\
\hline I cannot find the startup money & 21.9 & [1.8] & 45.6 & [2.1] \\
\hline I think, I do not have what it takes & 18.7 & [1.7] & 38.1 & [2.1] \\
\hline Entrepreneurship is too risky & 15.6 & [1.6] & 50.7 & [2.2] \\
\hline I would not know what kind of business to start & 7.6 & [1.1] & 28.3 & [1.9] \\
\hline I would not know how to start & 6.5 & [1.1] & 30.6 & [2.0] \\
\hline $\begin{array}{l}\text { Business may involve breaking the law, I cannot/ do } \\
\text { not want to do that }\end{array}$ & 5.0 & [0.9] & 31.9 & [2.0] \\
\hline Too hard, I would need to work too much work & 4.3 & [0.9] & 19.3 & [1.7] \\
\hline I have more important goals in life than making money & 3.3 & {$[0.8]$} & 20.0 & [1.7] \\
\hline Current job brings more money & 3.0 & [0.7] & 8.9 & [1.2] \\
\hline I am afraid that my products/services will not sell & 1.3 & [0.5] & 18.0 & [1.7] \\
\hline $\begin{array}{l}\text { The attitude of my family and friends towards } \\
\text { entrepreneurs is hostile }\end{array}$ & 0.6 & [0.3] & 6.9 & [1.1] \\
\hline $\begin{array}{l}\text { The attitude of local government towards entrepreneurs } \\
\text { is hostile }\end{array}$ & 0.6 & [0.3] & 8.7 & [1.2] \\
\hline $\begin{array}{l}\text { The attitude of central government towards } \\
\text { entrepreneurs is hostile }\end{array}$ & 0.2 & {$[0.2]$} & 4.3 & [0.9] \\
\hline $\begin{array}{l}\text { The attitude of the majority of population towards } \\
\text { entrepreneurs is hostile }\end{array}$ & 0.0 & {$[0.0]$} & 7.4 & [1.1] \\
\hline $\begin{array}{l}\text { The attitude of regional government towards } \\
\text { entrepreneurs is hostile }\end{array}$ & 0.0 & {$[0.0]$} & 5.4 & [1.0] \\
\hline Other & 10.6 & [1.3] & 16.7 & [1.6] \\
\hline
\end{tabular}

Note: Standard errors are in brackets. 